\title{
Systematic Separation Studies on Finely Dispersed Raw Magnesite by Using Triboelectrostatic Belt Separation
}

\author{
Sabrina Gehringer, Christoph Luckeneder, and Helmut Flachberger
}

Chair of Mineral Processing, Department Mineral Resources Engineering, Montanuniversität Leoben, Leoben, Austria

Received July 2, 2020; accepted July 7, 2020; published online July 20, 2020

\begin{abstract}
In the course of this study, systematic test series were examined to analyse and optimise the sortability of raw magnesite by using triboelectrostatic belt separation. The objective of the study was to find a dry sorting process for the separation of raw magnesite from accompanying components such as other carbonates and silicates. The aim of this test series was to develop knowledge about the optimal operating parameters for the triboelectrostatic separation of raw magnesite. All sorting tests were carried out with a triboelectrostatic belt separator type "ST X2" in an air-conditioned room at the Chair of Mineral Processing, Montanuniversität Leoben, Austria.
\end{abstract}

Keywords: Electrostatic separation, Mineral processing, Raw magnesite, Dry processing methods

Systematische aufbereitungstechnische Untersuchungen an feindispersem Rohmagnesit mittels triboelektrostatischer Bandscheidung

Zusammenfassung: Im Rahmen dieser Studie wurden systematische Versuchsreihen durchgeführt, um die Sortierbarkeit von Rohmagnesit unter Verwendung der triboelektrostatischen Bandscheidung zu analysieren und in weiterer Folge zu optimieren. Ziel der Studie ist es, ein trockenes Sortierverfahren zu finden, um die Begleitkomponenten des Rohmagnesits - wie andere Karbonate und Silikate - möglichst vollständig abzutrennen. Ziel dieser Versuchsreihen war es, Erkenntnisse über die optimalen Betriebsbedingungen für die Sortierung von Rohmagnesit zu gewinnen. Alle Sortierversuche wurden mit einem triboelektrostatischen Bandabscheider der Type "ST X2" in ei-

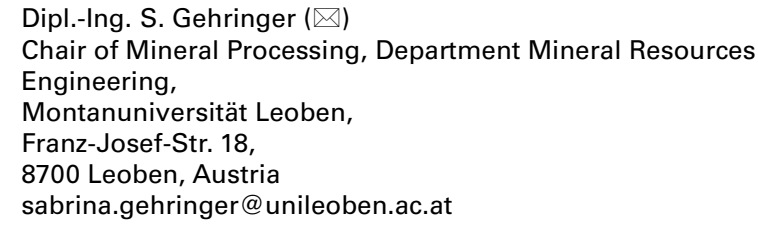

nem klimatisierten Raum im Aufbereitungstechnikum des Lehrstuhls für Aufbereitung und Veredlung durchgeführt.

Schlüsselwörter: Elektrostatische Sortierung, Mineralaufbereitung, Rohmagnesit, TrockenSortierverfahren

\section{Introduction and Motivation}

Raw magnesite is found in most deposits along with limestone, dolomite, ferruginous minerals, quartz and other silicates. The most important quality criteria for magnesite concentrates are the contents of $\mathrm{MgO}, \mathrm{CaO}, \mathrm{SiO}_{2}$ and for some applications also $\mathrm{Fe}_{2} \mathrm{O}_{3}$. These components lower the melting point, which negatively affects the processing of the magnesite concentrate. In the coarse fractions the concentration of magnesite is often achieved by utilising selective extraction and crushing, manual and sensor-based sorting, density sorting and dry magnetic separation. For achieving a separation effect in the fractions smaller than one millimetre wet processing technologies such as wet magnetic separation and flotation are applied. Especially for the fraction smaller than $200 \mu \mathrm{m}$ flotation is to some extend irreplaceable.

Due to natural breakage characteristics of crude ores fractions smaller than $200 \mu \mathrm{m}$ will always be resulting from mining, crushing and milling activities. Dumping those fractions contradicts economic pressure nowadays. The maximization of recovery of minerals in the mined ore is necessary for a successful mining operation. The responsibility towards future generations of the minimization of wasting natural resources leads to the same direction.

Nevertheless, a sustainable and future-orientated usage of a deposit makes the processing of the fractions smaller than $200 \mu \mathrm{m}$ necessary. Due to the increasing demand for high-grade concentrates, the importance of a separation technology for fractions smaller than $200 \mu \mathrm{m}$ will increase in the future. In situations and areas where access to water for processing is limited or not available, a water-free 
Fig. 1: Operation principle of a triboelectrostatic belt separator [7]

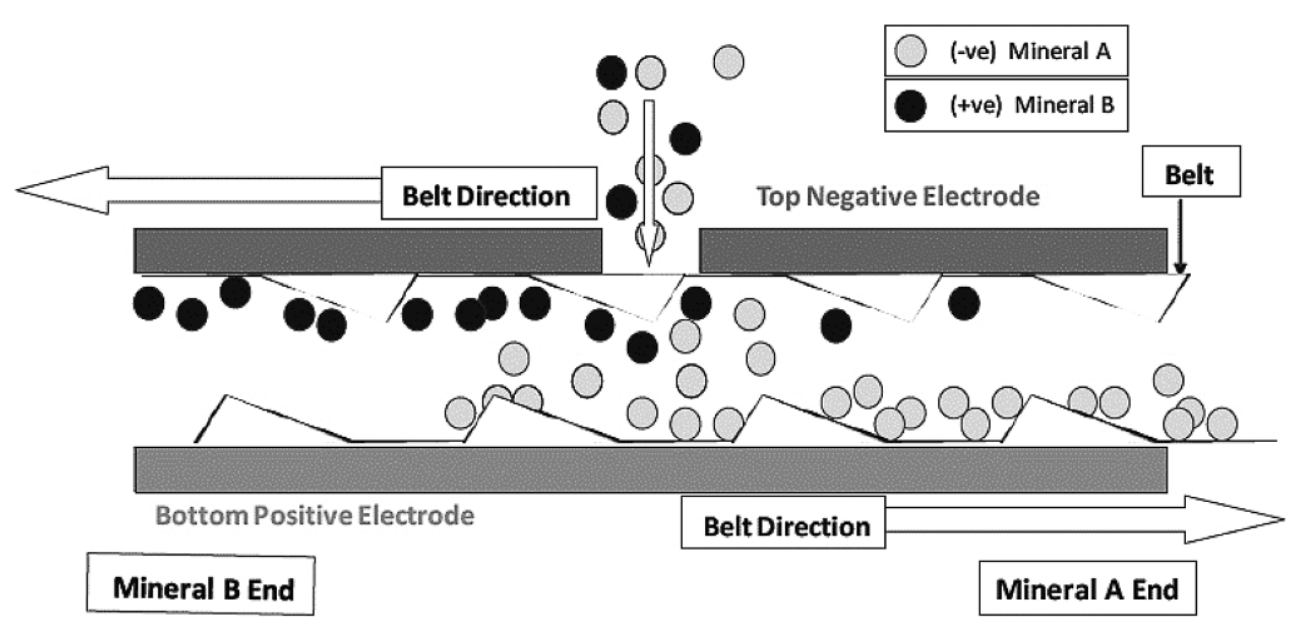

The processing of mixtures of non-conductors is based on differences in the surface work function. The generation of the charge differences of the particle surfaces is called tribo polarization. In case the difference in surface work function is high enough, one particle is charged positively and the other one negatively when getting into contact. The separation is done by utilising free-fall separators and belt separators.

Within this paper, the separation tests were conducted using an electrostatic belt separator including the charging of the particles by utilising a triboelectrostatic effect. In the case of the triboelectrostatic belt separator the particles are charged through particle to particle, particle to electrode and particle to belt collisions. The intensity of this electron transfer depends on the size of the contact surface as well as the contact duration, frequency and strength. Often collision effects inside upstream units such as vibro feeders, fluidised bed dryers and cyclones have a charging effect, too [4-6].

The operation principle of a triboelectrostatic belt separator is shown in Fig. 1; [7].

\section{Characterization of the Raw Magnesite Sample}

To obtain a first impression of the raw magnesite sample, the chemical composition and a particle size distribution were determined. The results of the chemical analysis are summarised in Table 1, the particle size distribution in the logarithmic grid is shown in Fig. 2. According to supplier information, the sample consists of the minerals magnesite, calcite, dolomite, quartz and talc. The charging of the particle surfaces is done by induction or with a corona electrode. For the separation of conductors versus non-conductors mostly drum separators are in use. of conductors versus non-conductors and the separation of non-conductors versus non-conductors.

The separation of conductors versus non-conductors is versus non-conductors mostly drum separators are in use.

\begin{tabular}{|llllll}
\hline \multicolumn{7}{|l|}{ TABLE 1 } & \multicolumn{7}{l|}{} \\
\multicolumn{4}{l}{ Chemical composition of the raw magnesite sample } & \\
\hline $\mathrm{MgO}$ & $\mathrm{CaO}$ & $\mathrm{SiO}_{2}$ & $\mathrm{R}_{2} \mathrm{O}_{3}$ & Acid insoluble components & Loss in ignition \\
\hline$[\%]$ & {$[\%]$} & {$[\%]$} & {$[\%]$} & {$[\%]$} & {$[\%]$} \\
\hline 36.1 & 2.5 & 13.0 & 2.1 & 19.5 & 40.9 \\
\hline
\end{tabular}




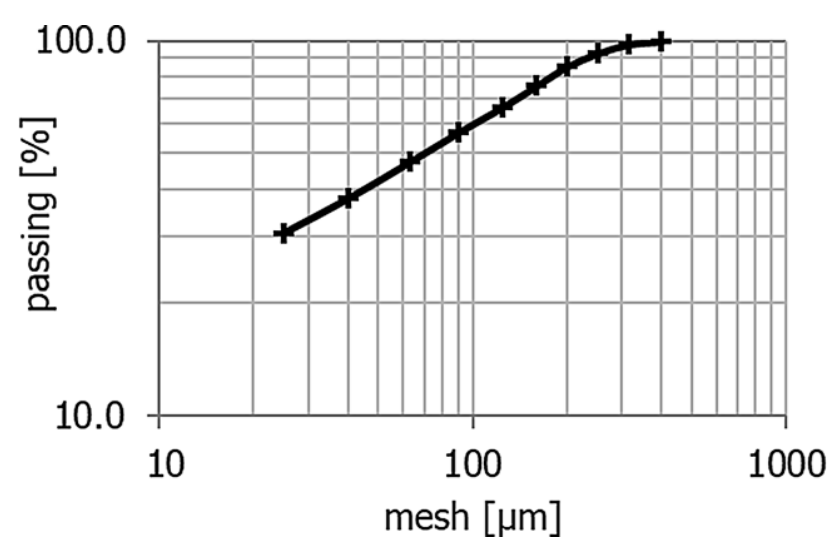

Fig. 2: Particle size distribution of the raw magnesite sample in the logarithmic grid

\section{Experimentation}

\subsection{Experimental Setup}

The separation tests were carried out at the "ST X2" triboelectrostatic belt separator. The operational principle has already been shown in Fig. 1. The feed sample passes from above via a vibrating unit into the electrostatic field, which is generated via electrodes arranged one above the other. In the gap between the electrodes a belt, which is basically a large mesh, is running towards itself in a continuous loop. The belt takes care of intensive feed material charging. The charged particles are dragged to the electrodes with the opposite polarisation and are then transported by the belt in the respective direction. The polarity of the electrodes can be reversed on both sides. Product discharge takes place on the left and right side of the machine after leaving the electrostatic field. The two products are collected in bags [8].

\subsection{Experimental Design}

The experimental design is based on the statistical design of experiments, which is a further development of traditional experimental design methods. Through detailed planning and targeted change of influencing factors, the efficiency of the experimental setup can be increased $[8,9]$.

\subsection{Machine Settings for the Separation of Raw Magnesite}

The triboelectrostatic belt separator enables the variation of numerous parameters. In order to gain knowledge about the influence of these parameters on the separation efficiency of the raw magnesite sample, these and their interactions with each other were analysed in detail. For the execution of the separation tests, a fractional factorial test design of type " $2^{5-1 "}$ was chosen $[8,9]$. The separation success was assessed by determining the chemical composition by means of XRF in combination with the acid insoluble residue and the loss on ignition.

For the determination of the machine settings for the separation of raw magnesite the following machine parameters were changed on the lab scale belt separator: [8]
a) applied voltage
b) electrode distance
c) belt speed
d) polarity of the top electrode
e) feed rate

Ad a) The voltage applied to the electrodes can be infinitely adjusted from 0 to $6 \mathrm{kV}$. For the tests, the levels for the applied voltage were set at 3 and $6 \mathrm{kV}$ [8].

$\mathrm{Ad} \mathrm{b}$ ) The electrode distance is limited by the geometric conditions. For the maximum distance a value of $14 \mathrm{~mm}$ was determined, for the minimum it was $9 \mathrm{~mm}$. These two extremes were taken as a level in the experimental design plan [8].

Ad c) A belt speed of $35.2 \mathrm{fps}(10.9 \mathrm{~m} / \mathrm{s})$ was defined as the upper level in the design plan. For the lower level $17 \mathrm{fps}$ $(5.2 \mathrm{~m} / \mathrm{s})$ was selected [8].

Ad d) The polarity of the top and bottom electrode can be set positive or negative. For the generation of an electrostatic field, one electrode must always be positive and one negative. For the experiments, both variants were implemented. Further information on the polarity always refers to the head electrode [8].
Fig. 3: Effect diagram for the applied test program

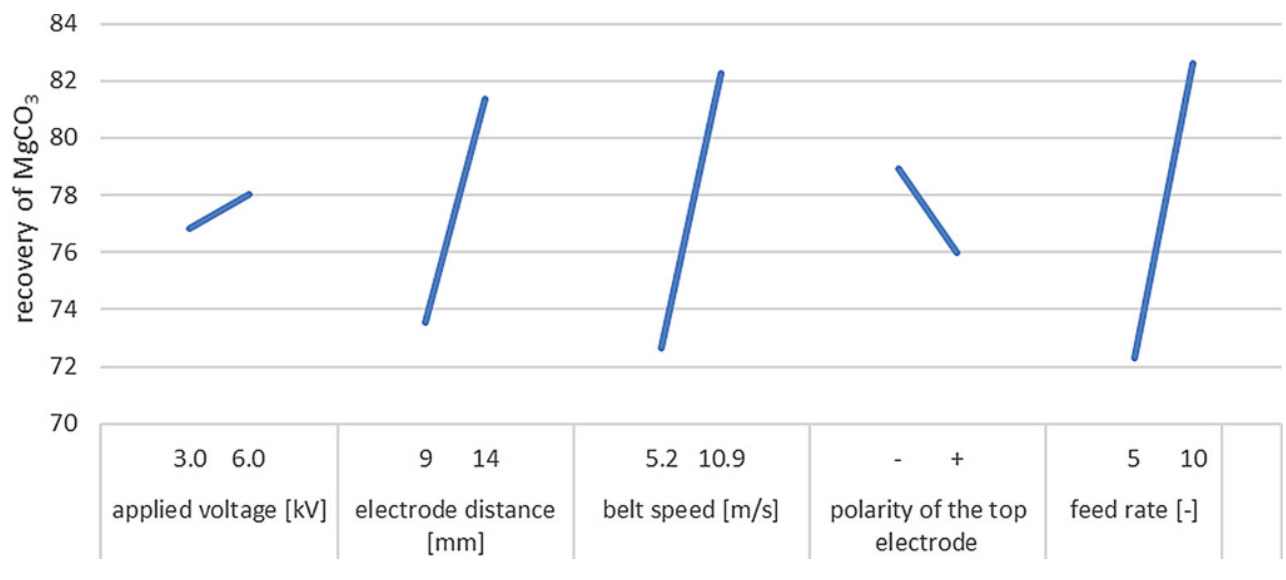




\begin{tabular}{|c|c|c|c|c|c|}
\hline \multirow[t]{2}{*}{ Test number } & Belt speed & Gap between the electrodes & Applied voltage & Polarity of the top electrode & Feed rate \\
\hline & [fps] & {$[\mathrm{mm}]$} & {$[\mathrm{kV}]$} & $(+/-)$ & $(1-10)$ \\
\hline 1 & 17.0 & 9 & 3 & $(-)$ & 10 \\
\hline 2 & 17.0 & 9 & 6 & $(-)$ & 5 \\
\hline 3 & 35.2 & 9 & 3 & $(-)$ & 5 \\
\hline 4 & 35.2 & 9 & 6 & $(-)$ & 10 \\
\hline 5 & 17.0 & 14 & 3 & $(-)$ & 5 \\
\hline 6 & 17.0 & 14 & 6 & $(-)$ & 10 \\
\hline 7 & 35.2 & 14 & 3 & $(-)$ & 10 \\
\hline 8 & 35.2 & 14 & 6 & $(-)$ & 5 \\
\hline 9 & 17.0 & 9 & 3 & $(+)$ & 5 \\
\hline 10 & 17.0 & 9 & 6 & $(+)$ & 10 \\
\hline 11 & 35.2 & 9 & 3 & $(+)$ & 10 \\
\hline 12 & 35.2 & 9 & 6 & $(+)$ & 5 \\
\hline 13 & 17.0 & 14 & 3 & $(+)$ & 10 \\
\hline 14 & 17.0 & 14 & 6 & $(+)$ & 5 \\
\hline 15 & 35.2 & 14 & 3 & $(+)$ & 5 \\
\hline 16 & 35.2 & 14 & 6 & $(+)$ & 10 \\
\hline
\end{tabular}

TABLE 3

Balance sheet of the most successful separation test

\begin{tabular}{llll}
\hline & Yield & Grade $-\mathrm{MgCO}_{3}$ & Recovery $-\mathrm{MgCO}_{3}$ \\
\hline & {$[\%]$} & {$[\%]$} & {$[\%]$} \\
\hline Concentrate & 78.9 & 97.9 & 90.7 \\
\hline Tailings & 21.1 & 33.7 & 9.3 \\
\hline Feed & 100.0 & 76.5 & 100.0 \\
\hline
\end{tabular}

Ad e) The feed rate of the vibro feeder can be adjusted from 1 to 10 . The values 5 (about $120 \mathrm{~g} / \mathrm{min}$ ) and 10 (about $250 \mathrm{~g} / \mathrm{min}$ ) were defined as levels [8].

The levels of the parameters a) to e) given here were taken over into a fractional factorial test design of the type " $2^{5-1 "}$ which is illustrated in Table 2.

During the execution of the tests, the machine settings were changed as previously defined in the design plan in Table 2. The environmental influences of the system were kept constant as far as possible. The room temperature during all tests was about $25^{\circ} \mathrm{C}$, the relative humidity about $30 \%$.

\section{Results and Discussion}

The assessment of the machine settings for the separation of raw magnesite was carried out by the average values of the $\mathrm{MgCO}_{3}$ grade and recovery in the concentrate at the 16 different setting combinations (according to Table 2).

The average values were calculated from the results obtained at the different levels, from the two mean values at setting (maximum) and (minimum) the difference between these two values was also formed, which describes the intensity of the influence of the factor [8].

The effect diagram for the applied test program (Fig. 3) indicates the influence of the factors on the separation re- sult. Electrode distance, belt speed and feed rate had a big influence on the separation result. Increasing the level resulted in increasing $\mathrm{MgCO}_{3}$ recovery. Increasing applied voltage increased the $\mathrm{MgCO}_{3}$ recovery as well, but the impact on the separation result was quite low. A negatively charged top electrode resulted in a higher $\mathrm{MgCO}_{3}$ recovery than a positively charged top electrode.

The balance sheet of the most successful separation test is shown in Table 3. The $\mathrm{MgCO}_{3}$ grade was increased from $76.5 \%$ in the feed to $87.9 \%$ in the concentrate with a yield of $78.9 \%$. $90.7 \%$ of the $\mathrm{MgCO}_{3}$ was reported to the concentrate, just $9.3 \%$ of the $\mathrm{MgCO}_{3}$ was lost to the tailings product.

Fig. 4 presents a comparison of the recoveries of $\mathrm{MgCO}_{3}$ versus $\mathrm{CaCO}_{3}$ in the products. The recoveries of $\mathrm{MgCO}_{3}$ and $\mathrm{CaCO}_{3}$ correlate to a greater extent. The fact that there are no intergrown particles to be expected in the test feed proves that magnesite, dolomite and calcite were transported to the same product. There was not one single test resulting in magnesite, dolomite and calcite being recovered in different products.

The position of the minerals in the triboelectric series also defines this trend [10].

The associated machine settings for the separation of raw magnesite are summarised in Table 4. 


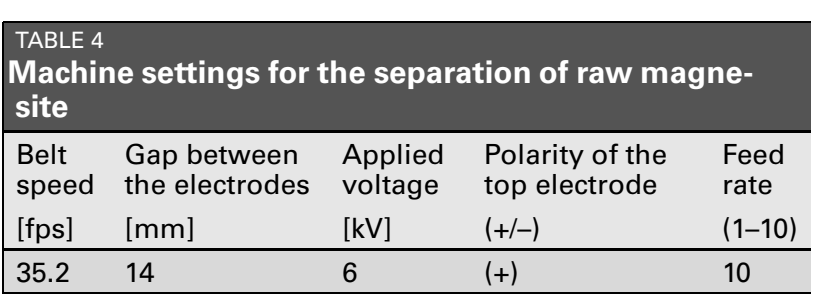

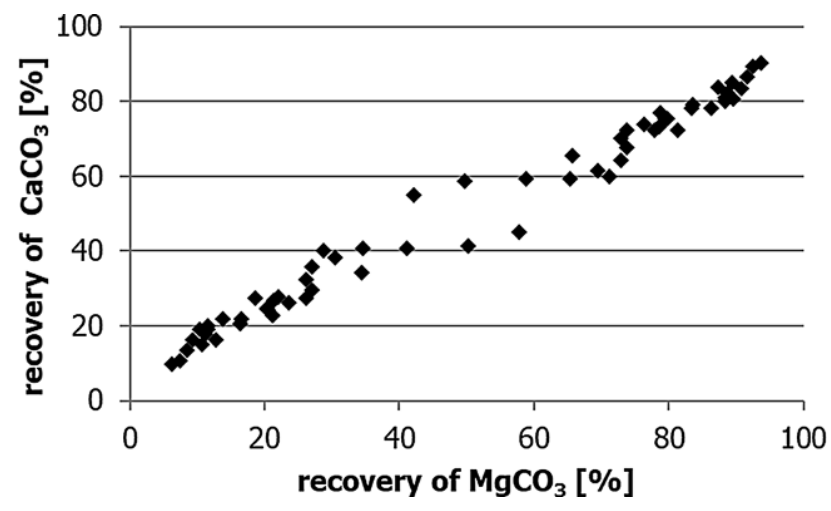

Fig. 4: Recovery of $\mathrm{CaCO}_{3}$ versus recovery of $\mathrm{MgCO}_{3}$

\section{Conclusion}

In course of the presented study the sortability of raw magnesite with the "STX2" triboelectrostatic belt separator was confirmed. For an efficient separation, the optimum machine parameters for this raw material (Table 4) must be set.

The presented separation test series showed an impressive separation performance between carbonates and silicates. High mass and $\mathrm{MgCO}_{3}$ recovery in the concentrate combined with a significant increase of the $\mathrm{MgCO}_{3}$ grade in the concentrate prove the applicability of the technology for the tested raw material.

The comparison of the recoveries of $\mathrm{MgCO}_{3}$ and $\mathrm{CaCO}_{3}$ indicate that the carbonates in the feed sample resulted in the same separation behaviour. A separation effect regarding the containing carbonates was not achieved. All tests resulted in a concentrate consisting of a mixture of the carbonates.

Funding. Open access funding provided by Montanuniversität Leoben.
Open Access This article is licensed under a Creative Commons Attribution 4.0 International License, which permits use, sharing, adaptation, distribution and reproduction in any medium or format, as long as you give appropriate credit to the original author(s) and the source, provide a link to the Creative Commons licence, and indicate if changes were made. The images or other third party material in this article are included in the article's Creative Commons licence, unless indicated otherwise in a credit line to the material. If material is not included in the article's Creative Commons licence and your intended use is not permitted by statutory regulation or exceeds the permitted use, you will need to obtain permission directly from the copyright holder. To view a copy of this licence, visit http://creativecommons.org/licenses/by/4.0/.

\section{References}

1. Wang, Q. Q.; Li, X. A.; Wei, D. Z.; Dai, S. J.: The Application of Magnesite Processing Technics. Applied Mechanics and Materials, vol 71-78, July 2011, pp 2323-2326

2. rhimagnesita:https://www.rhimagnesita.com/de/(Accessed 20.03 . 2020)

3. Styromag Steirische Magnesitindusrtie GmbH: https://www.styro mag.at/de/\%C3\%BCber-uns/unternehmenspolitik/ (Accessed 04.06.2020)

4. Heinrich, S.: Aufbereitung fester mineralischer Rohstoffe, Bd. 2: Sortierprozesse, 4. Aufl., Stuttgart: Deutscher Verlag für Grundstoffindustrie, 1996

5. Manouchehri, H.-R.: Triboelectric Charge Characteristics and Electrical Separation of Industrial Minerals, Doctoral thesis, Luleå Univ. of Technology, Department of Chemical and Metallurgical Engineering, 2000

6. Oberrauner, A.; Flachberger, H.: Beitrag zur Untersuchung der triboelektrischen Aufladecharakteristik feindisperser Körnerschwärme, BHM Berg- und Hüttenmännische Monatshefte, 155 (2010), iss. 12, pp 565-570

7. Hrach, F.; Flynn, K.; Miranda, P. J.: Beneficiation of industrial minerals using a tribo-electrostatic belt separator, XXVIII International Mineral Processing Congress (IMPC) 2016, Quebec City, Canada: Canadian Institute of Mining Metallurgy and Petroleum (CIM), 2016

8. Gehringer, S.; Flachberger, H.; Luckeneder, C.; Hrach., F.: Processing of caustic calcined magnesite (magnesium oxide) by the use of triboelectrostatic belt separation, BHM Berg- und Hüttenmännische Monatshefte 164 (2019), pp 303-309

9. Siebertz, K.; Bebber, D.; Hochkirchen, T.: Statistische Versuchsplanung. Design of Experiments (DoE), Berlin: Springer, 2010

10. Ferguson, D.N.: A basic triboelectric series for heavy minerals from inductive electrostatic separation behaviour, in: The 7th International Heavy Minerals Conference “What next”, Drakensburg 2009. The Southern African Institute of Mining and Metallurgy, Symposium series S57, Johannesburg: SAIMM, vol. 110 (2010), pp. 129-134

Publisher's Note. Springer Nature remains neutral with regard to jurisdictional claims in published maps and institutional affiliations. 